\title{
Staining Acidic Phosphoproteins (Phosvitin) in Electrophoretic Gels
}

The principal phosphoglycoproteins of avian and amphibian egg yolk, known as phosvitins, have been examined extensively in developmental studies of estrogenic induction of protein synthesis (1) and, more recently, as substrates for protein kinases which phosphorylate the basic nuclear proteins $(2,3)$. Phosvitin has few aromatic and basic amino acids (4) which can be detected by uv absorbance or by conventional anionic protein stains following electrophoresis. In addition, the high negative-charge density of clustered phosphorylserine residues (2) may prevent staining by charge repulsion of anionic dyes. Dilute solutions of cationic dyes like toluidine blue and acridine orange have been employed $(5,6)$, but, in our experience, they penetrate gels slowly and also stain the residual negative charges of most electrophoretic matrices, including agarose, starch, and even polyacrylamide. The only specific method for localizing phosphoproteins in polyacrylamide gels requires several time-consuming steps to liberate orthophosphate by basic hydrolysis, to form an insoluble phosphomolybdate complex, and, finally, to stain this complex with methyl green dye (7). The exceptional affinity of contiguous phosphorylserines for trivalent metal ions (8) can, however, be exploited to detect phosvitin in gels. This strategem may also provide an alternative method for visualizing similar acidic phosphoproteins which have now been identified in brain, spermatozoa, and adrenal medulla $(9,10)$.

\section{Quantitative Detection of apo-Phosvitin by Coomassie blue Stain with Aluminum Mordant}

Coomassie brilliant blue $\mathrm{R} 250$ in acid solution stains $\mathrm{Al}(\mathrm{III})$-phosvitin but does not bind to the metal-free apo-protein (Fig. 1, A and B). Aluminum

FIG. 1. Staining of Fe(III)- and apo-phosvitin in polyacrylamide gels. Gel composition: $9 \%$ acrylamide, $0.05 \% N, N^{\prime}$-methylenebisacrylamide, $0.032 \% N, N, N^{\prime}, N^{\prime}$-tetramethylethylenediamine, $0.07 \%$ ammonium peroxydisulfate, and $0.037 \mathrm{M}$ Tris- $\mathrm{HCl}$ buffer $(\mathrm{pH} 8.62)$. Electrophoretic conditions: $5 \mathrm{~mA} / \mathrm{cm}^{2}, 55 \mathrm{~min}, 22^{\circ} \mathrm{C}$. Protein samples and stains: Protein samples were mixed with $50 \mu \mathrm{l}$ of $5 \%$ glycerol for application to the gel column $(5 \times 60 \mathrm{~mm})$. (A) Sample: $5 \mu \mathrm{g}$ of chicken apo-phosvitin from Calbiochem $(5 \mu \mathrm{l})$; stain: $0.05 \%$ Coomassie brilliant blue R250 in a solution of $25 \%$ isopropanol/10\% acetic acid/1\% Triton X-100; destain: $7 \%$ acetic acid. (B) Sample: $5 \mu \mathrm{g}$ of apo-phosvitin $(5 \mu \mathrm{l})$; stain: $0.05 \%$ Coomassie blue in a solution of $0.1 \mathrm{~m}$ aluminum nitrate $/ 25 \%$ isopropanol $/ 10 \%$ acetic acid/1\% Triton X-100; destain: 7\% acetic acid. (C) Sample: $5 \mu \mathrm{g}$ of apo-phosvitin $(5 \mu \mathrm{l})+5 \mu \mathrm{l}$ of $5 \mathrm{~mm}$ Fe(III)-nitrilotriacetate 1:1 chelate [see Ref. (8)]; stain: $0.2 \%$ potassium ferrocyanide in $10 \%$ trichloroacetic acid; no destain necessary. 


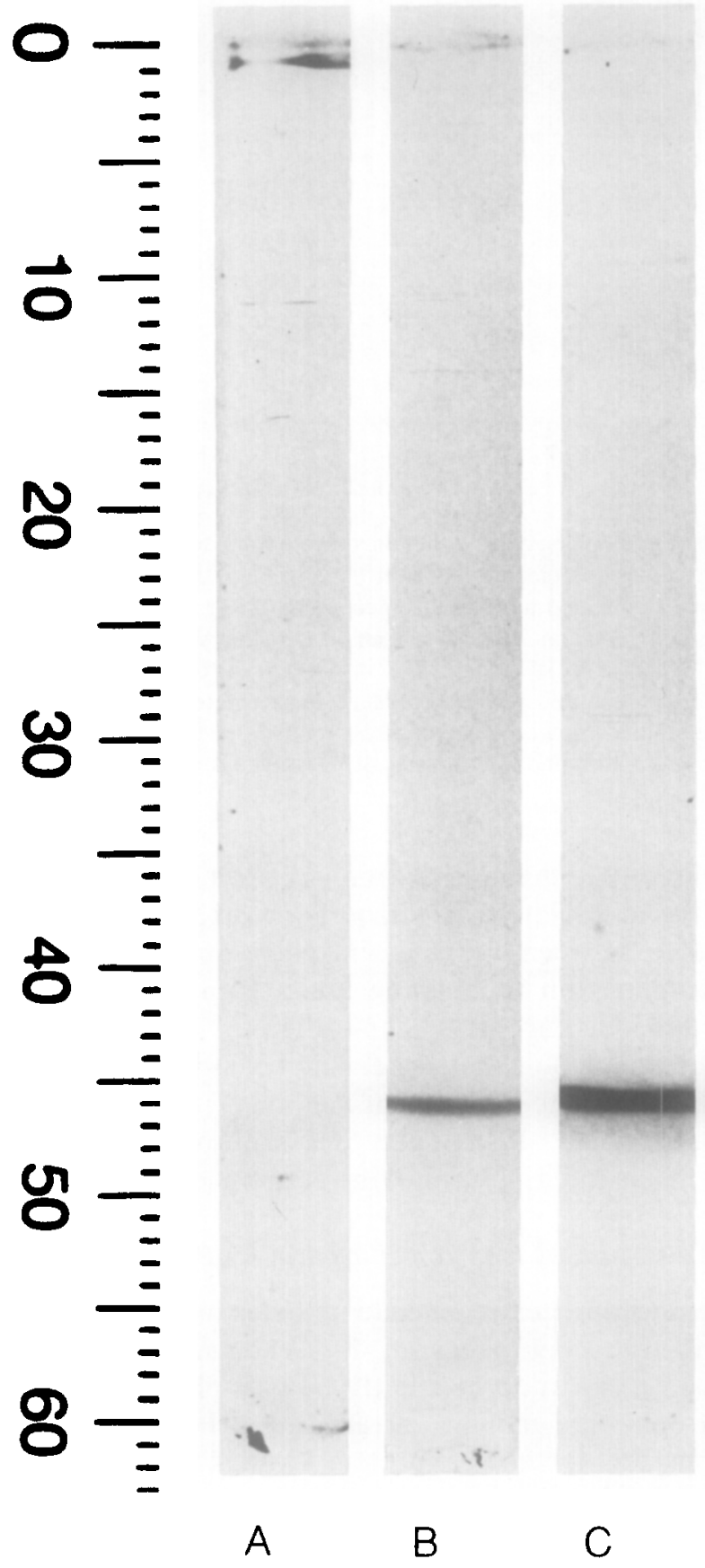




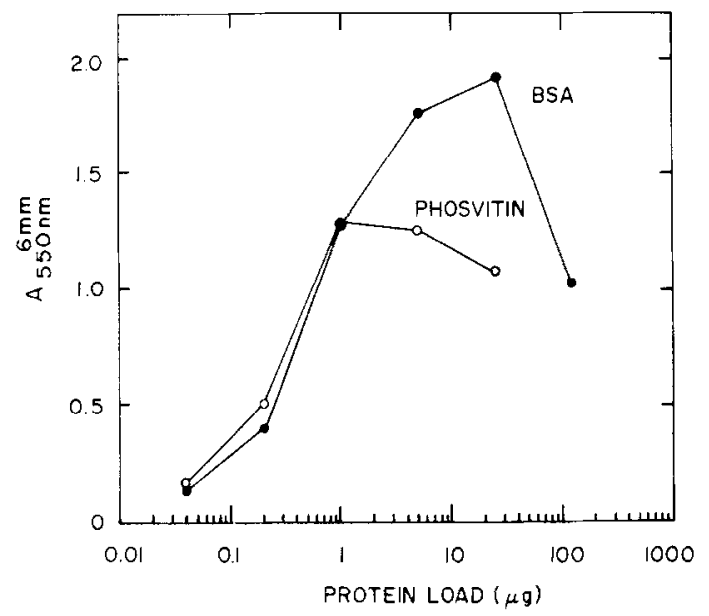

FIG. 2. Absorbance of phosvitin zones in polyacrylamide gels stained with aluminum/ Coomassie blue. Dilutions of apo-phosvitin (Calbiochem) and of a reference standard of crystalline bovine serum albumin [defatted according to Ref. (12)] were applied in a volume of $5 \mu \mathrm{l}$ to individual polyacrylamide gels, then electrophoresed and stained with aluminum/ Coomassie brilliant blue R250 as described in the legend to Fig. 1. After destaining, gels were scanned in a 6-mm cell with a recording densitometer to obtain the absorbance at the peak of the stained protein zone. Peak absorbance decreased at higher protein loads because protein was distributed in a wider, poorly resolved zone and because stain penetrated the gel unevenly.

salts added directly to the dye solution will promote formation of a metalprotein chelate in which $\mathrm{Al}(\mathrm{III})$ damps the strong negative charge and acts as a bridge between dye and phosphorylserine residue. As little as $40 \mathrm{ng}$ of apo-phosvitin (containing about $0.13 \mathrm{nmol}$ of phosphate) is easily detectable in our gel system (Fig. 2). Staining phosvitin with aluminum/Coomassie blue thus appears to be considerably more sensitive than the orthophosphate-entrapment method (7) which could detect only $1 \mathrm{nmol}$ of phosphate. If the gels are not overloaded with protein, phosvitin stains as intensely as bovine serum albumin (Fig. 2).

\section{Qualitative Detection of Iron(III)-Phosvitin by Prussian blue Reaction}

The ferric-nitrilotriacetate chelate donates iron(III) specifically and stoichiometrically to apo-phosvitin (8). When fully saturated, iron(III)phosvitin has a molar ratio of $1 \mathrm{Fe}$ (III):2 phosphorylserine residues and has an electrophoretic mobility at alkaline $\mathrm{pH}$ that is not significantly different from the metal-free protein (Fig. 1, B and C). The ironprotein is easily visualized as "ferric ferricyanide" deposits (11) after soaking electrophoretic gels in any one of a variety of histochemical Prussian blue stains (Figure 1C). In our experience, intensity of staining is directly proportional to the amount of iron presented to the phosvitin 
sample prior to electrophoresis, providing the iron-binding capacity of the phosvitin has not been exceeded.

\section{ACKNOWLEDGMENTS}

This work was supported by U.S. Public Health Service Grants AM 12386, CA 06929. and GM 05409 and by a contract from the Dairy Council of California.

\section{REFERENCES}

1. Wallace, R. A., and Jared, D. W. (1968) Science 160, 91-92.

2. Pinna, L. A., Donella, A., Clari, G., and Moret, V. (1975) Biochim. Biophys. Acta 397, 519-528.

3. Williams, R. E. (1976) Science 192, 473-474.

4. Wallace, R. A. (1963) Biochim. Biophys. Acta 74, 505-518.

5. Culbert, J., and McIndoe, W. M. (1971) Int. J. Biochem. 2, 617-622.

6. Kamiya, M., and Okuyama, T. (1973) Seikagaku [J. Japan. Biochem. Soc.] 45, 327-335.

7. Cutting, J. A., and Roth, T. F. (1973) Anal. Biochem. 54, 386-394.

8. Webb, J., Multani, J. S., Saltman, P., Beach, N. A., and Gray, H. B. (1973) Biochemistry 12, $1797-1802$.

9. Heald, P. J. (1961) Biochem. I. 80, 510-514.

10. Brooks, J. C., and Siegel, F. L. (1973) Biochem. Biophys. Res. Comm. 55, 710-716.

11. Lillie, R. D., and Donaldson, P. T. (1974) Histochem. J. 6, 679-684.

12. Chen, R. F. (1967) J. Biol. Chem. 242, 173-181.

JACK HEgenAuER

LARRY RIPLEY

GEORGE NACE ${ }^{1}$

Department of Biology, B-022

University of California, San Diego

La Jolla, California 92093, and

${ }^{1}$ Department of Zoology \& Center for Human Growth and Development

University of Michigan

Ann Arbor, Michigan 48109

Received July 22, 1976; accepted October 22, 1976 